\title{
Application of GPR in the study of shallow subsurface sedimentary architecture of Modwa spit, Gulf of Kachchh
}

\author{
S B Shukla, A K Patidar and Nilesh Bhatt \\ Department of Geology, Faculty of Science, M. S. University of Baroda, Vadodara 390 002, India. \\ e-mail: nilesh_geol@yahoo.com
}

\begin{abstract}
The coastline constitutes a very sensitive geomorphic domain constantly subjected to dynamic coastal processes. The study of its ever-changing physiography and stratigraphy provides a wealth of information on its history and evolution, in many cases at decadal and annual scales. The present study was carried out on the Modwa beach complex between Rawal Pir and Modwa, about $10 \mathrm{~km}$ east of Mandvi on the northern coast of the Gulf of Kachchh. The Modwa spit is a 7-km long WNW-ESE trending prograding amalgamated beach ridge complex that is about $0.5 \mathrm{~km}$ wide at its western end and $1.5 \mathrm{~km}$ wide at its eastern end. This Ground-Penetrating Radar (GPR) survey delineated a variety of the radar surfaces and radar facies which reflects not only large scale sedimentary architecture, but depositional facies of the beach ridge complex. These are bounding surfaces separating the radar facies outline beach ridge (br), washover (wo), coastal dune (cd) and swale (sw) depositional environments. The internal sedimentary structures like tangential, parallel, concave and convex upward stratifications could also be visualized from the GPR profiles. The architecture suggests the formation of this complex due to a combined process of eastward littoral drift of locally derived sediments and its onshore deposition by storms and eolian activities.
\end{abstract}

\section{Introduction}

Reconstruction of past sedimentary environment is possible using data describing sediment body geometry, internal architecture and physical and biological structures, and the textural and compositional characteristics of the sediments. Examination of the shallow subsurface sedimentary architecture has been attempted by digging a trench or hunting for a natural section. It is usually very difficult to encounter such exposed sections in an active coastal depositional system subjected to episodic erosion by storm events. Digging a trench is also costly and many times not permitted due to environmental impact. Ground-Penetrating Radar (GPR) proves to be an important noninvasive tool in studies of coastal landforms and depositional environments due to its capability to image the sedimentary structures and depositional architecture in the shallow subsurface. Correctly processed radar profiles have been used successfully to construct the radar stratigraphy in both, ancient and modern sand bodies (Jol and Smith 1991; Gawthorpe et al 1993). The use of GPR in sedimentology requires systematic collection, processing and interpretation of the radar profile with awareness about distortions of reflection and the reception of discrete pulses of high frequency electromagnetic waves by the sediments in varied textural and moisture conditions.

To understand the ongoing coastal processes, examination of its sedimentary architecture up to a shallow depth is useful as it represents the dynamics during the recent past. The present work is focused on evaluating the GPR technique in understanding the shallow subsurface architecture of part of an amalgamated beach ridge complex. The Modwa area was selected for this study because of its clean sand and good exposure on the northern coast of the Gulf of Kachchh. The sand of the

Keywords. Ground-Penetrating Radar; radar stratigraphy; coastal geomorphology; Gulf of Kachchh. 


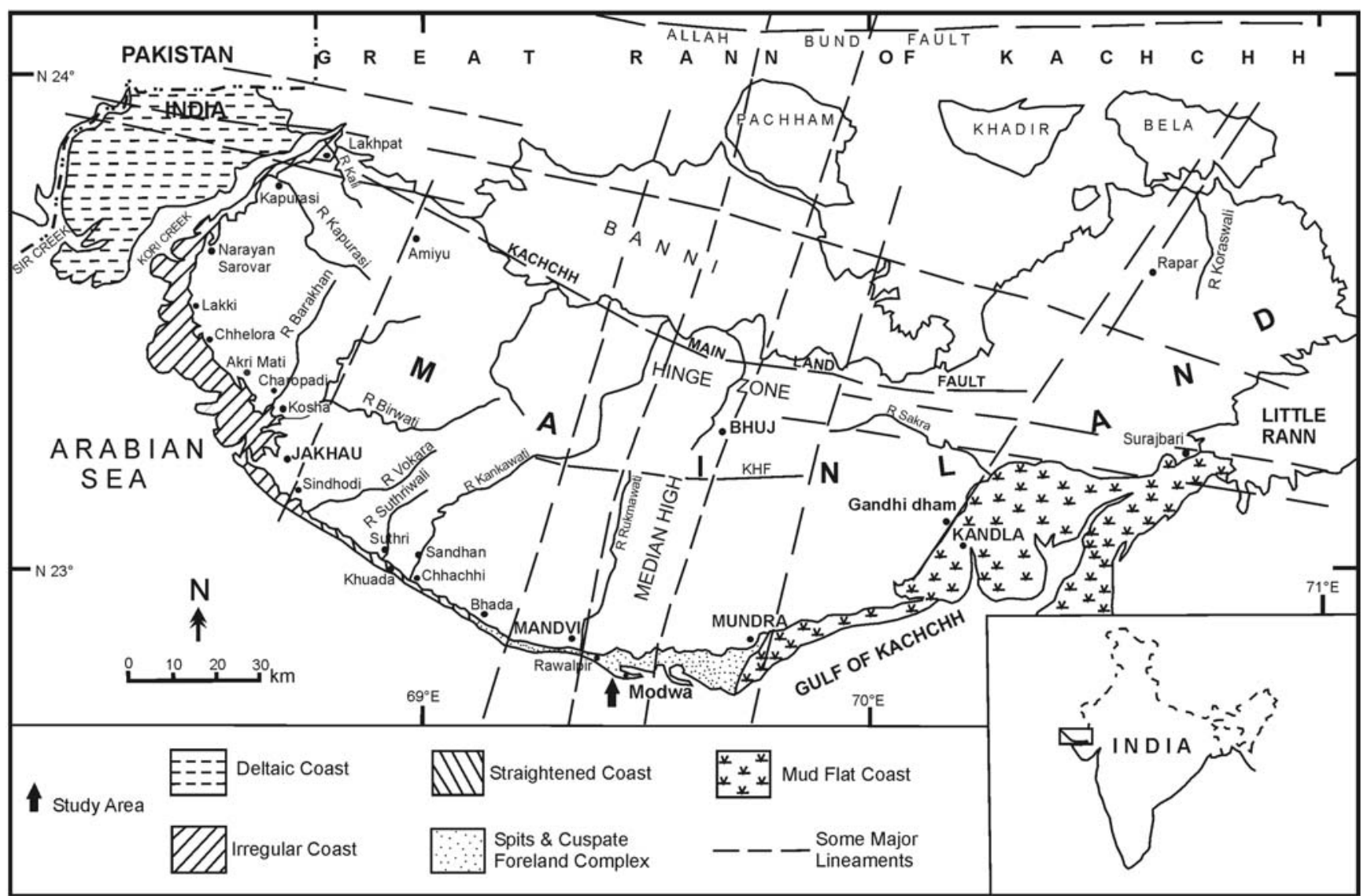

Figure 1. Regional geomorphic setup of the Kachchh coastline (after Kar 1993).

Modwa beach complex range in size from -0.5 phi to 1.5 phi having about $92 \%$ of quartz and a very less amount of the magnetic minerals. To check the radar penetration depth and distinct reflection of the ground water table, a pit of $2 \mathrm{~m}$ depth was dug at the starting point of the profile collected on the Dhrabudi Mata coast.

\section{Study area}

The coastline of the Kachchh exhibits three distinct depositional energy domains that have unique geomorphological attributes. The northeastern part between Sir Creek and Kori Creek exhibits a network of tidal channels and has been classified as the deltaic coast by Kar (1993). The coastline between Narayan Sarovar and Jakhau has irregular nature whereas, from Jakhau to Khuada it is relatively straight; a sandy amalgamated beach ridge/dune complex and wide tidal flats characterize the remainder of the coastline (figure 1). This study was carried out in the area between Rawal Pir and Modwa, about $10 \mathrm{~km}$ east of Mandvi. This part of the coastline is characterized by a $7-\mathrm{km}$ long WNW-ESE trending prograding beach ridge complex that is about $0.5 \mathrm{~km}$ wide at its western end.
The beach is about $1.5 \mathrm{~km}$ wide at its eastern end (figure 2a). The adjacent coastline shows ancient and active tidal flats with muddy sediments abutting against the sandy coastal plain (figure $2 \mathrm{~b}$ ). The satellite image clearly shows a linear pattern formed due to preferred growth of the vegetation (mainly Acacia and its species) along the swales between the beach ridges due to the availability of water (figure 2a). The orientation of these swales and beach ridges define the progradation process as being a result of eastward littoral drift of sediment. An active spit growth at the eastern end provides evidence for this inference (figure 1). A wide intertidal and associated supratidal domain exhibits a variety of depositional sub-facies such as ridgerunnel-berm, berm plain, swash, washover - foreshore and backshore dunes. Patel et al (2001) have also discussed the ravine zone in the coastal plain associated with the rivers like Kharod, Rukmavati, Phot, Nagavanti and Bhukhi.

\section{GPR studies}

\subsection{Principle and application}

GPR that is also known as ground-penetrating radar, subsurface penetrating radar, subsurface 
(a)

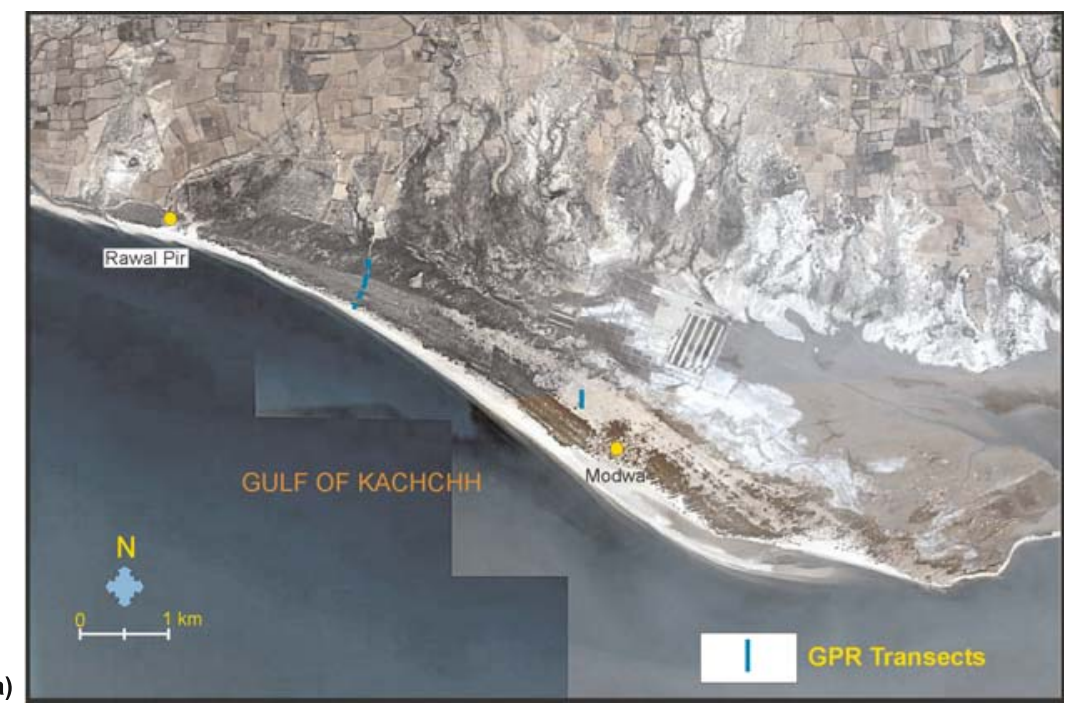

(b)

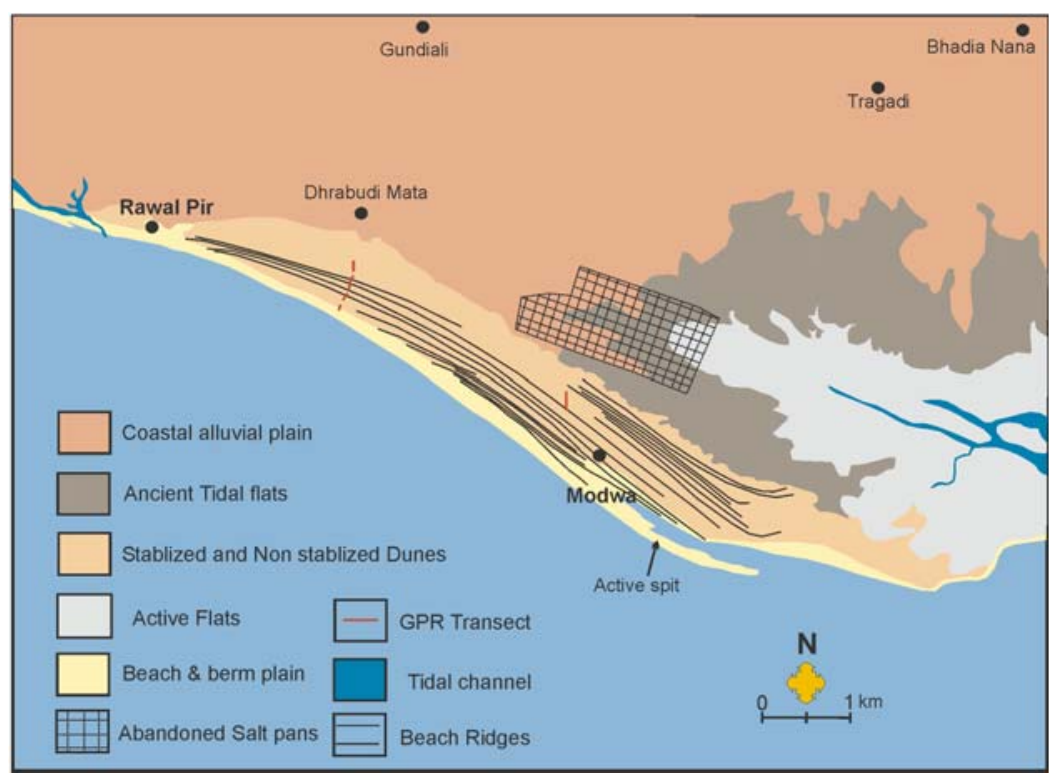

Figure 2. (a) A GoogleEarth image showing Modwa beach-ridge complex. A number of beach ridges are seen due to linear confinement of the vegetation along swales. Active growth of the spit can also be seen at its southeastern end. (b) Geomorphic setup of the Modwa and adjoining coastal area.

radar, georadar or impulse radar is a nondestructive geophysical technique which detects electrical discontinuities in the shallow subsurface using a system setup that can generate, transmit, receive and record the discrete pulses of high frequency (1 to $1000 \mathrm{MHz}$ ) electromagnetic energy (Neal 2004). Although the technique has been employed in a variety of sedimentary environments, it is not very simple to interpret the radar profiles due to the complexity of the deposits and multiple returns of the waves. In geological material, the propagation of electromagnetic waves is controlled by properties like relative dielectric permittivity $(\varepsilon r)$, relative magnetic permeability $(\mu r)$ and electrical conductivity $(\sigma)$. When a propagating electromagnetic wave encounters a distinct discontinuity with respect to $\varepsilon r$, $\mu r$ or $\sigma$, some energy is reflected which is proportional to the magnitude of the relative change in these properties (Reynolds 1997; Van Dam and Schlager 2000). Very commonly the water table, sedimentary structures and lithological boundaries become visible in radar profiles for these reasons. A depositional (bedding) plane in sediments is a product of changes in sediment composition and changes in size, shape, orientation and packing of grains (Collinson and Thompson 1989). A number of studies have successfully shown relationship between the GPR reflections and sedimentary structures especially with the help of rigorously processed data (Annan 1999; Neal and Roberts 2000; Corbeanu et al 2001; Jol et al 2002; Hammon et al 2002; Buynevich and FitzGerald 2003; Neal et al 2003 and Neal 2004). The technique has been 


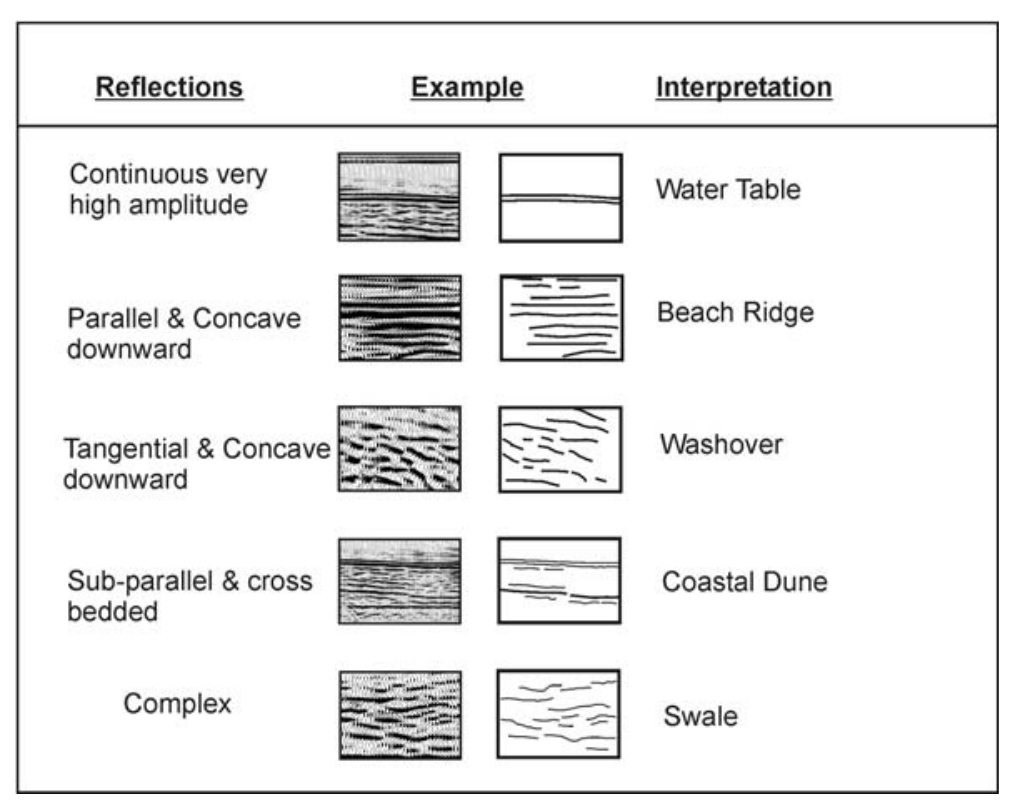

Figure 3. Major radar facies encountered in the GPR profiles of Modwa complex.

successfully employed using same GPR system in India wherein the correlations between the reflections and subsurface reflectors were established by trenching (Sridhar and Patidar 2005; Maurya et al 2006).

\subsection{Data acquisition and processing}

The Geophysical Survey Systems Inc, USA (GSSI) make SIR-20 GPR system has been used for the present study. A $200 \mathrm{MHz}$ center frequency monostatic shielded antenna attached with an odometer based survey wheel was dragged continuously along the selected profile line (figure 2) to acquire the GPR data. The positions of end points of these profiles were recorded using Geoexplorist 210 GPS. The profiles were collected in distance mode with 512 samples/scan and 16 Bits/sample resolution. The range of the time window defer from 100-160 ns. Some long profiles were raised along the profile line and some interesting transects were repeated and marked for the final data acquisition. The post processing of data was carried out using the Radan software.

The raw GPR data contain interference from the external objects and subsurface discontinuities in the form of noise. These GPR signals were analyzed in the frequency spectrum and the band pass filters were used to remove the noise. The deconvolution and migration functions were applied to remove the effect of scattering of signals and to rearrange the dipping reflections at their true position (Annan 1999; Jol et al 2002; Costas et al 2006). The post-processing also included the application of automatic gain control (AGC) function to make low-amplitude signals more visible. The GPR system noise can be readily identified due to its appearance at regular interval along the profile, having relatively consistent amplitude (Annan and Daniels 1998). Gawthorpe et al (1993), McMechan et al (1997) and Corbeanu et al (2001) have demonstrated the GPR applications in sedimentological characterization of the sand bodies in ancient geological records.

\subsection{GPR profiles}

Total eight GPR profiles were collected from the Modwa beach complex near Dhrabudi Mata temple and Modwa fishermen village. Five profiles were taken continuously on a road from the Dhrabudi Mata temple to the foreshore area. However, due to the unfavourable ground conditions, these profiles are not of very good quality. It is also not possible to present all the profiles due to its repetitive nature and hence, two best profiles out of these eight profiles are described here under that sample the gross characteristics of the radar facies. Based on the previous studies (Neal 2004; Costas et al 2006) and the typical nature of the tangential, concave upward, concave downward and parallel reflectors, four radar facies have been recognized (figure 3).

\section{3a Profile I}

This profile was taken from south to north direction normal to the shoreline, starting from the berm-line to backshore dune field. The $30 \mathrm{~m}$ long profile was initiated from $22^{\circ} 48.306^{\prime} \mathrm{N} ; 69^{\circ} 24.497^{\prime} \mathrm{E}$ 
(a)

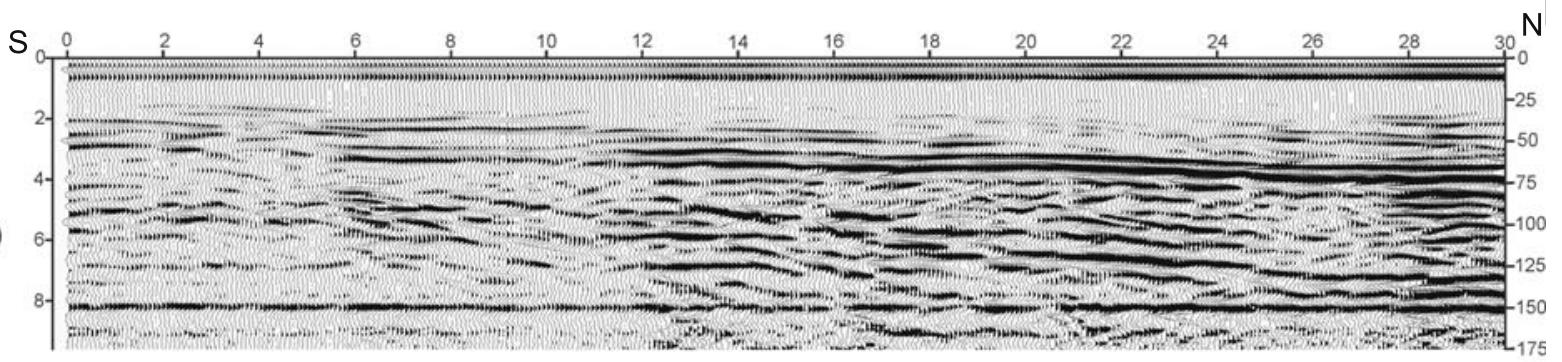

(b)

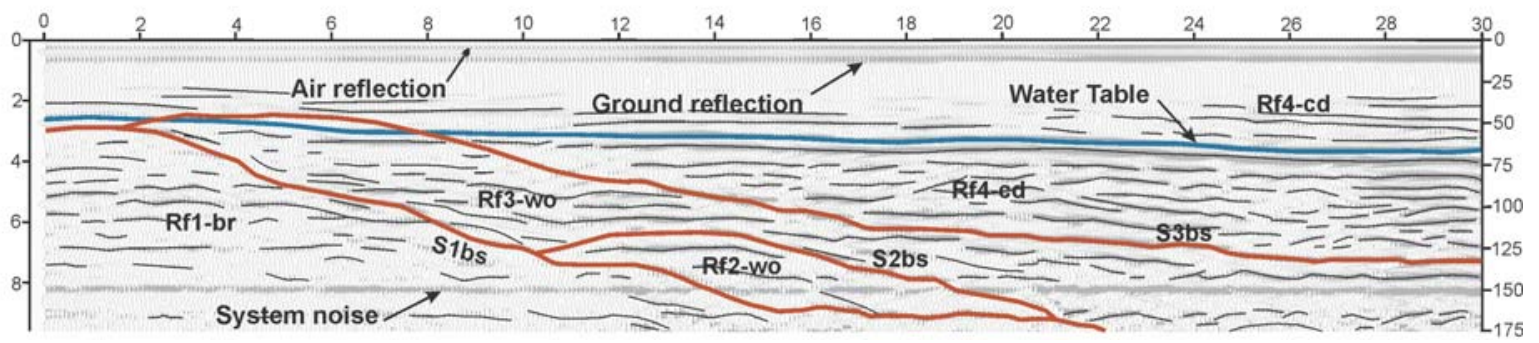

Figure 4. (a) $200 \mathrm{MHz}$ GPR profile from the coast of Dhrabudi Mata temple shown in wiggle mode. (b) Various radar surfaces $S_{1}$ bs to $S_{3}$ bs (bs - bounding surface) and facies $\mathrm{Rf}_{1}$ to $\mathrm{Rf}_{4}$ are interpreted from this. Radar facies br - beach ridge, wo - washover and cd - coastal dune also exhibit typical tangential, concave upward and downward internal reflectors.

(a)

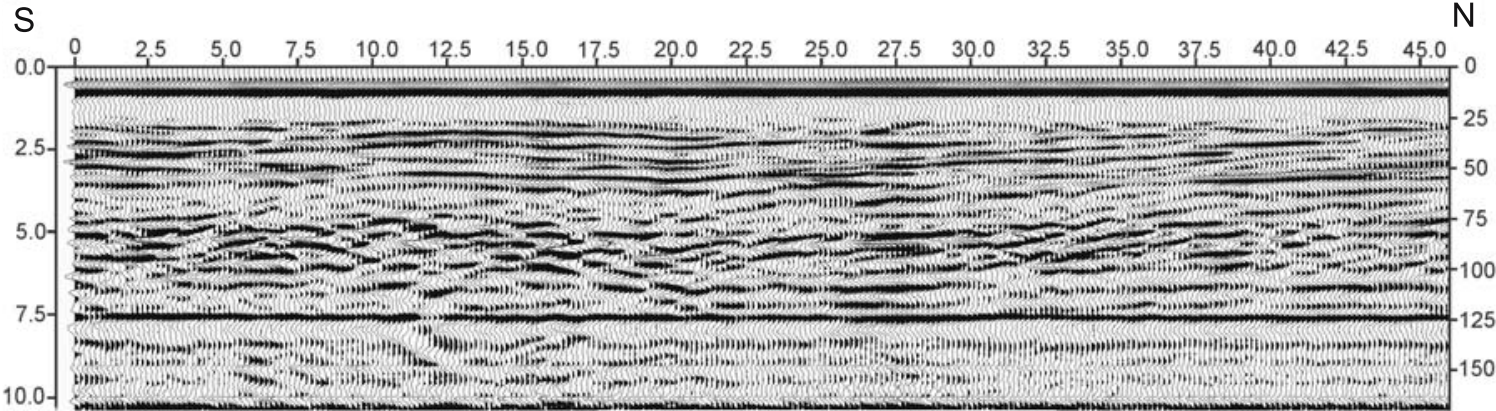

$\mathrm{N}$

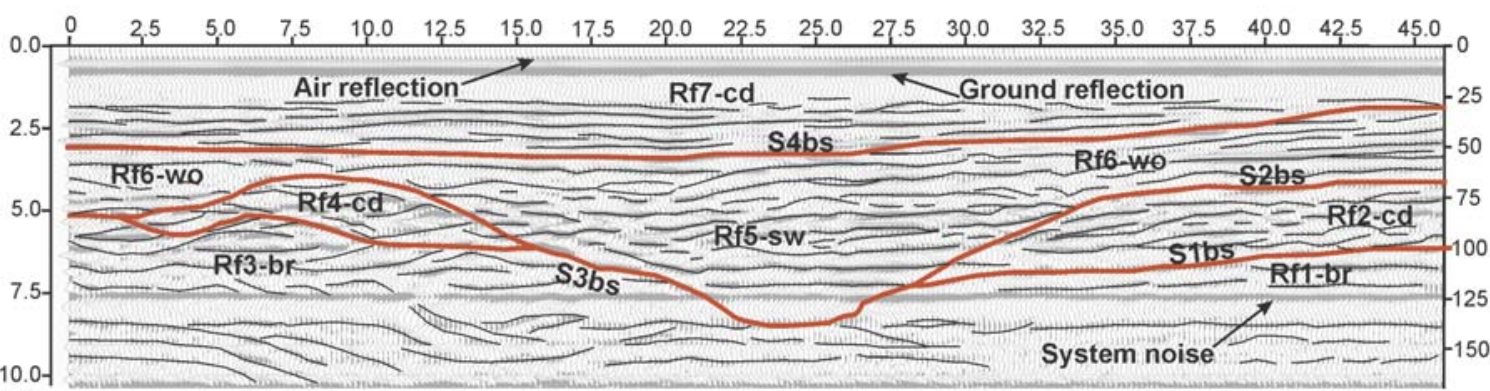

Figure 5. (a) $200 \mathrm{MHz}$ GPR profile in wiggle mode from the Modwa village. (b) Various radar surfaces $\mathrm{S}_{1} \mathrm{bs}$ to $\mathrm{S}_{4} \mathrm{bs}$ (bs - bounding surface) and radar facies $\mathrm{Rf}_{1}$ to $\mathrm{Rf}_{7}$ can be seen from this. Radar facies br - beach ridge, sw - swale, wo - washover and cd - coastal dune also exhibit typical tangential, concave upward and downward internal reflectors.

and ended at $22^{\circ} 48.325^{\prime} \mathrm{N} ; 69^{\circ} 24.503^{\prime} \mathrm{E}$. The topmost uniform reflections represent air waves that are followed by very distinct high amplitude reflections visible as a thick black line are derived from the ground waves and are seen up to the depth of $0.8 \mathrm{~m}$ (figure 4). Another very prominent reflection can be seen at the depth of 3.5 to $4 \mathrm{~m}(75 \mathrm{~ns})$ in the form of two thick lines. This represents the ground water table (Costas et al
2006). The water is of brackish nature. A distinct line at the depth of $8 \mathrm{~m}$ can also be seen along the complete length of profile. Its uniform amplitude and depth suggest that it is the system noise. Although, attenuation of the radar signals becomes profound below this reflection, the continuation of the inclined reflectors can be still seen. As the dug well data in the nearby coastal plain indicate much deeper (more than 
$30 \mathrm{~m}$ ) occurrence of the Pre-Quaternary substrate, the possibility of this continuous reflector being underlying coastal plain hard ground is ruled out. The profile (figure 4) clearly shows three radar surfaces that bound the radar facies characterized by its own style of reflections. Following the procedure suggested by Neal (2004), these surfaces have been designated as the bounding surfaces $\left(\mathrm{S}_{1}\right.$ bs, $\mathrm{S}_{2}$ bs and $\mathrm{S}_{3} \mathrm{bs}$ ) whereas, the facies as $\mathrm{Rf}_{1}$ to $\mathrm{Rf}_{4}$ with abbreviations represent its depositional environments.

The radar facies characterized by continuous sub-horizontal, parallel and very gently seaward dipping and concave downward with relatively higher landward dipping reflections are interpreted as the beach ridge (br) reflections (Psuty 1965; Collinson and Thompson 1989). Near the base of a beach ridge mainly horizontally laminated sand units are found separated by an erosional surface from the substrate; the concave downward units follow this towards the land which may be interpreted as the swash or washover facies (wo). The cross bed sets and cosets have been successfully recognized within the GPR by Corbeanu et al (2001). The washover facies are reflected by discontinuous, relatively more inclined landward dipping $\left(7^{\circ}-12^{\circ}\right)$, low amplitude reflectors with tangential-oblique configuration. During exceptional high tides aided by storms, more sediment can be eroded from the subtidal and intertidal areas and deposited further landward in the form of washover fans (Schwartz 1982; Neal et al 2003; Reineck and Singh 1980). The small scale reflectors containing radar facies which dip in different directions and at different angles with occasional discontinuous bounding surfaces are described earlier as eolian deposits by Schenk et al (1993), Van Heteren et al (1998) and Costas et al (2006). Here it is considered as coastal dune (cd) facies as it occurs at a higher elevation towards land.

\section{3b Profile II}

Like the previous one, this $46 \mathrm{~m}$ profile was also collected from south to north between $22^{\circ} 47.604^{\prime} \mathrm{N}$; $69^{\circ} 26.070^{\prime} \mathrm{E}$ and $22^{\circ} 47.630^{\prime} \mathrm{N} ; 69^{\circ} 26.077^{\prime} \mathrm{E}$ (figure 5). As discussed in the first profile, the prominent reflections pertaining to the air and ground reflections as well as the system noise are quite visible at the top of the profile and at $7.5 \mathrm{~m}$ (125 ns) depth, respectively. The profile exhibits four radar surfaces. $S_{1}$ bs marks the top of an ancient beach ridge at the depth of about $6 \mathrm{~m}$, as it is characterized by more or less parallel radar facies. This can be seen overlain by the coastal dune facies. The radar surface $S_{3}$ demarcates a unique package that exhibits sub-parallel to slightly discontinuous facies $\left(\mathrm{Rf}_{3}\right.$ br $)$ related to the subsequent beach ridge towards south, separated by a depression hosting another parallel radar facies $\left(\mathrm{Rf}_{5} \mathrm{sw}\right)$. The $\mathrm{Rf}_{3}$ br grades upward into the cross bedded reflection showing dips in both the directions. This $\mathrm{Rf}_{4} \mathrm{~cd}$ pertains to the wind built upper part of the beach ridge and $\mathrm{Rf}_{5} \mathrm{sw}$ can be described as a swale between two successive beach ridges (Otvos 2000). An undulating radar surface $\mathrm{S}_{4}$ bs separates the parallel to sub-parallel prominent reflections that grade into gently southward dipping cross-bedded facies $\left(\mathrm{Rf}_{7} \mathrm{~cd}\right)$ which has been interpreted as obliterated or slightly modified coastal dune facies in the light of the ground truth. In total, this radar profile manifests the prograded nature of the Modwa beach complex with its aggradation mainly due to the eolian processes.

\section{Discussion and conclusion}

The study of the ever-changing physiographic and stratigraphic record of the coastal depositional system provides a wealth of information on its past history at much higher temporal scale; in many cases decadal and annual (Moore et al 2004). There exists a very delicate balance between the tides, currents, waves and onshore winds that shape out the overall architecture of the coastal sediment bodies. Observation and understanding of such record can be used in a predictive manner to understand the possible effect of anthropogenic activities in the area as the coastlines which are becoming favoured sites for economic hubs in recent times. The Modwa area is one such area, lying within the upcoming Mundra Special Economic Zone.

Because of the non-destructive nature and capabilities of repetitive observation, the GPR technique is gaining popularity among earth scientists interested in shallow depth. The survey carried out under this study could demonstrate recognition of various sedimentary reflectors that can be suitably interpreted as bounding surfaces and facies, manifesting a gross sedimentary architecture of the body. The study indicates major radar surfaces that delineate depositional facies, reflecting the dynamic nature of this beach ridge system. These bounding surfaces and radar facies delineate beach ridge (br), washover (wo), coastal dune (cd) and swale (sw) depositional facies. Similar facies have been identified by adopting the principles of radar stratigraphy in the coastal areas of England (Neal and Roberts 2001; Neal et al $2002,2003)$. The GPR data and the surface expression of the amalgamated beach ridges, outlined by vegetated linear swales (figure 2a), confirm the progradational history of the Modwa beach. 
The first order radar surfaces enclose beach ridge facies formed in response to the onshore and longshore currents. These surfaces form subparallel to gently seaward dipping reflectors. The sediment depositing on top of this facies characteristically shows landward dipping reflectors which indicate washover fan deposition (Reineck and Singh 1980). The washover fans generally resulted during the increased water level with more sediment known as heavy sea (Andrews 1970) which happens during the storms. The Gulf of Kachchh has a history of storm events, many being very devastating, during recent times. The upper part of the Modwa complex in near shore areas near Dhrabudi Mata temple as well as in distal parts like Modwa village is composed of coastal dunes that exhibit tangential and concave downward reflectors in a stacked manner. The onshore winds in the study area are mostly southwesterly having a velocity of $15 \mathrm{~km} / \mathrm{h}$ during calm season that becomes stormy during the summer monsoon (May-August months). Being semi-arid to arid climatic zone, the eolian deposition is almost a continuous process along the Kachchh coast. The study of sediment transport in the gulf region has indicated that the sediments enter into the mouth of the Gulf of Kachchh from north as well as south directions and its movements are season dependent (Kunte et al 2003). The Gulf of Kachchh has a well defined high velocity tidal stream in the central part and also the ebb tide jets that does not allow significant longshore transportation of the sediments derived from the Indus River (Nair et al 1982). So, the sediments constituting the Modwa complex must be derived from the local source. From the architecture, it appears that the progradation of Modwa beach complex is chiefly due to the eastward littoral drift and onshore monsoon winds which redistribute the sediments derived from the Tertiary rocks of the coastal plain, and drained by the Rukmavati River that debouches at the western end of the complex (figure 1). Part of the sediments must be drawn from the erosion of the older beach ridge complex near the mouth of the Rukmavati River as can be seen in the form of 3 $4 \mathrm{~m}$ high cliffs exposing the ancient beach ridge sediments. Although, several wave built and wind built facies could be delineated within the prominent radar surfaces, unavailability of the absolute ages does not allow deducing the evolutionary history of the Modwa beach-dune complex in this limited study. Studies on neotectonic activities (Kar 1993; Maurya et al in press), roles of dynamic processes (tides, waves, currents and winds) and a dependable geochronology is highly warranted to reconstruct the morpho-dynamic evolution and history of this beach ridge complex during the recent geological past.

\section{Acknowledgements}

This is a contribution to the DST sponsored ongoing research programme on Science of Shallow Subsurface (DST No. SR/S4/ES21/Kachchh Window/P6). The GPR facility has been made available under another project (DST/23(324)/SU/2001). Prof. L S Chamyal and Dr. D M Maurya are thankfully acknowledged for the encouragement, guidance and timely help in the field as well as in the department. We are grateful to the JESS reviewers whose constructive comments have greatly improved the earlier version of this paper.

\section{References}

Andrews P B 1970 Facies and genesis of a hurricane washover fan, St. Joseph Island, Central Texas coast; Bur. Econ. Geol., Univ. Texas, Austrin Rep. 67 147pp.

Annan A P 1999 Practical processing of GPR data; Sensors and software, Ontario.

Annan A P and Daniels J J 1998 Foundation of GPR for three dimensions; Sensors and software, Ontario.

Buynevich I V and FitzGearald D M 2003 High resolution subsurface (GPR) imaging and sedimentology of coastal ponds, Maine, USA: implications for Holocene back-barrier evolution; J. Sediment. Res. 3 559-571.

Collinson J D and Thompson D B 1989 Sedimentary structures; $2^{\text {nd }}$ edn (London: Unwin Hyman) 207 pp.

Corbeanu R M, Soegaard K, Szerbiak R B, Thurmond J B, McMechan G A, Wang D, Snelgrove S, Forster C B and Menitove A 2001 Detailed internal architecture of a fluvial channel sandstone determined from outcrop, cores and 3-D ground-penetrating radar: Example from the middle Cretaceous Ferron Sandstone, east-central Utah; AAPG Bulletin 85 1583-1608.

Costas S, Alfjo I, Rial F, Lorenzo $\mathrm{H}$ and Nombela M A 2006 Cyclical Evolution of a modern transgressive sand barrier in Northwestern Spain elucidated by GPR and aerial photos; J. Sediment. Res. 76 1077-1092.

Gawthorpe R L, Collier R E L, Alexander J, Leeder M and Bridge J S 1993 Ground-penetrating radar; application to sand body geometry and heterogeneity studies; Geol. Soc. London Spec. Publ. 73 421-432.

Hammon III W S, Zeng X, Corbeanu R M and Mcmechan G A 2002 Estimation of the special distribution of fluid permeability from surface and tomographic GPR data and core, with a 2-D example from the ferron sandstone, Utah; Geophysics 67 1505-1515.

Jol H M, Lawton D C and Smith D G 2002 Groundpenetrating radar: 2-D and 3-D subsurface imaging of a coastal barrier spit, Long beach, WA, USA; Geomorphology 53 165-181.

Jol H M and Smith D G 1991 Ground-Penetrating radar of Northern lacustrine deltas; Canadian J. Earth Science 28 1939-1947.

Kar A 1993 Neotectonic influence on morphological variation along the coastline of Kachchh, India; Geomorphology 8 199-219.

Kunte P D, Wagle B G and Sugimori Y 2003 Sediment transport and depth variation study of the Gulf of Kutch using remote sensing; Int. J. Remote Sensing $\mathbf{2 4}$ $2253-2263$. 
Maurya D M, Goyal B, Patidar A K, Mulchandani N, Thakkar M G and Chamyal L S 2006 Ground-penetrating radar imaging of two large sand blow craters related to the 2001 Bhuj earthquake, Kachchh, Western India; J. App. Geophys. 60 142-152.

Maurya D M, Thakkar M G, Patidar A K, Bhandari S, Goyal B and Chamyal L S 2007 Late Quaternary geomorphic evolution of the coastal zone of Kachchh, Western India; J. Coastal Research (in press).

McMechan G A, Gaynor G C and Szerbiak R B 1997 Use of ground-penetrating radar for 3-D sedimentological characterization of clastic reservoir analogs; Geophysics $\mathbf{6 2}$ 786-796.

Moore L J, Jol H M, Kruse S, Vanderburgh S and Kaminsky G M 2004 Annual layers revealed by GPR in the subsurface of a prograding coastal barrier southwest Washington, USA; J. Sedim. Res. 74 690-696.

Nair R R, Hashimi N H and Rao V P 1982 On the possibilities of high velocity tidal stream as dynamic barrier to the longshore transport: evidence from the continental shelf off the Gulf of Kutch, India; Marine Geol. 47 77-86.

Neal A and Roberts C L 2000 Application of groundpenetrating radar (GPR) to sedimentological, geomorphological and geoarchaeological studies in coastal environments; In: Coastal and Estuarine Environments; Sedimentology, Geomorphology and Geoarchaeology (eds) Pye K, Allen J R L; Geol. Soc. London Spec. Publ. 175 139-171.

Neal A, Pontee N I, Pye K and Richards J 2002 Internal structure of mixed-sand-and-gravel beach deposits revealed using ground penetrating radar; Sedimentology 49 789-804.

Neal A, Richards J and Pye K 2003 Sedimentology of coarse clastic beach ridge deposits, Essex, Southeast England; Sedim. Geol. 162 167-198.
Neal A 2004 Ground-penetrating radar and its use in sedimentology: principles, problems and progress; Earth Sci. Rev. 66 261-330.

Neal A and Roberts C L 2001 Internal structure of a trough blow out determined from migrated ground-penetrating radar profiles; Sedimentology 48 791-810.

Otvos E G 2000 Beach ridges - definitions and significance; Geomorphology 32 83-108.

Patel S J, Desai B G and Bhatt N Y 2001 Neotectonic evolution of coastal landform between Jakhau and Mundra, Gulf of Kachchh, Western India; Bull. Ind. Geol. Assoc. 34 221-232.

Psuty N P 1965 Beach ridge development in Tabasco, Mexico; Ann Assoc. Amer. Geogr. 55 112-124.

Reineck H E and Singh I B 1980 Depositional sedimentary environment; Springer-Verlag, 549 pp.

Reynolds J M 1997 An introduction to applied and environmental geophysics; Wiley Chichester.

Schwartz R K 1982 Bedform and stratification characteristics of some modern small scale washover sand bodies; Sedimentology 29 835-849.

Schenk C J, Gautier D L, Olhoeft G R and Lucius J E 1993 Internal structure of an aeolian dune using groundpenetrating radar; Spec. Publ. Int. Assoc. Sed. 16 61-69.

Sridhar A and Patidar A 2005 Ground-penetrating radar studies of a point bar in the Mahi river Basin, Gujarat; Curr. Sci. 89 183-189.

Van Dam R L and Schlager W 2000 Identifying causes of ground-penetrating radar reflections using time-domain refletometry and sedimentological analysis; Sedimentology 47 435-449.

Van Heteren S, FitzGerald D M, Mckinlay P A and Buynevich I V 1998 Radar facies of paraglacial barrier systems: coastal New England, USA; Sedimentology $\mathbf{4 5}$ $181-200$. 